\title{
Perbandingan Efektifitas Kombinasi Ampisilin dan Gentamisin dengan seftazidim Pada Pengobatan Sepsis Neonatorum
}

\author{
Melina Imran, Julniar M. Tasli, Herman Bermawi
}

\begin{abstract}
Beberapa penelitian terakhir melaporkan bahwa sensitifitas kuman terhadap ampisilin dan gentamisin yang lazim digunakan sebagai terapi sepsis neonatorum telah menurun sehingga digunakan sefalosporin generasi ketiga sebagai alternatif. Dilakukan penelitian uji klinik acak tersamar ganda terhadap 50 kasus tersangka sepsis neonatorum dengan tujuan untuk menilai perbandingan efektivitas kombinasi ampisilin dan gentamisin dengan seftazidim. Subyek penelitian adalah seluruh pasien yang dicurigai sepsis neonatorum dan memenuhi persyaratan penelitian. Data diperoleh dari anamnesis, pemeriksaan fisis dan laboratorium. Analisa statistik menggunakan $t$-test, chi square test dan Kruskal_Wallis, berdasarkan jenis data yang akan diolah. Dari hasil penelitian kelompok yang mendapat kombinasi ampisilin dan gentamisin $8,3 \%$ memberikan respons klinis baik (dengan $95 \%$ confidence limit: $1-27 \%$ ) dan $91,7 \%$ gagal. Sedangkan pada kelompok seftazidim $88,5 \%$ memberikan respons baik (dengan 95\% confidence limit: 69,8-97,6\%) dan 11,5\% gagal. Terdapat perbedaan yang sangat bermakna antara hasil pengobatan kombinasi ampisilin dan gentamisin dengan seftazidim. Hasil pengobatan seftazidim jauh lebih baik dibanding dengan kombinasi ampisilin dan gentamisin, RR 7,9 artinya risiko gagal kelompok kombinasi ampisilin dan gentamisin 7,9 kali lebih besar daripada kelompok seftazidim.
\end{abstract}

Kata kunci: sepsis neonatorum, seftazidim.

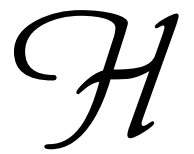

al terpenting dalam tatalaksana sepsis neonatorum adalah pemberian antibiotik yang tepat. Untuk menentukan jenis antibiotik perlu diketahui kuman yang paling sering menyebabkan sepsis neonatorum dengan melakukan biakan kuman dan uji resistensi. Sayangnya biakan kuman memerlukan waktu lama dan biaya yang mahal, sehingga sulit untuk mengetahui kuman penyebabnya, biasanya diberikan terapi secara empirik berupa antibiotik dengan spektrum luas yang dapat mencakup

Alamat korespondensi:

Dr. Julniar M Tasli Sp. A.

Bagian Ilmu Kesehatan Anak FK-UNSRI/RS Moh Hoesin Palembang. Jl. Jendral Sudirman km 3,5. Palembang

Telepon: 0711-354088 ext. 364/226. Fax. 0711-372832 / 354087. kuman Gram positif dan kuman Gram negatif. Di Subbagian Neonatologi Ilmu Kesehatan Anak Rumah Sakit Mohammad Hoesin (RSMH) Palembang digunakan pengobatan kombinasi ampisilin dan gentamisin pada neonatus.

Ketika digunakan pertama kali pada awal 1960, ampisilin sensitif terhadap sebagian besar galur E. coli, Proteus mirabilis, Salmonella, Shigella, dan N. gonorrhoeae. Namun sekarang terdapat peningkatan persentase spesies yang resisten terhadap ampisilin. Sekitar 30-50\% E.coli, P.mirabilis dan spesies Enterobakter telah resisten terhadap ampisilin, demikian juga Pseudomonas, Proteus indol positif dan Serratia. ${ }^{1}$ Resistensi bakteri Gram negatif terhadap gentamisin juga meningkat sebanding dengan jumlah obat yang digunakan di dalam lingkungan rumah sakit. Resistensi ini sering disebabkan karena penyebaran 
plasmid yang mengatur enzim yang berfungsi menonaktifkan gentamisin. $^{2}$

Tahun 1987 Monintja dan Faizah melakukan penelitian mengenai sensifitas kuman penyebab sepsis neonatorum terhadap ampisilin dan gentamisin. Pada penelitian tersebut didapatkan persentase sensitifitas kuman terhadap ampisilin yaitu Pseudomonas 7,14\%, E.coli 33,33\%, dan Klebsiella 0\%. Sedangkan terhadap gentamisin sensitifitas Pseudomonas 10,71\%, E.coli 66,66\% dan Klebsiella 40\%. Angka kematian penderita yang mendapat kombinasi ampisilin dan gentamisin adalah 80\% (Ranuh dkk, 1983) dan 80,9\% (Monintja $\mathrm{dkk}, 1986) .^{3}$ Tingginya angka kematian tersebut tampaknya berhubungan dengan besarnya angka resistensi terhadap ampisilin dan gentamisin.

Beberapa pusat telah mencoba mencari alternatif lain untuk pengobatan sepsis neonatorum yaitu misalnya sefalosporin. Sefalosporin mempunyai struktur mirip dengan penisilin (hingga saat ini telah berkembang sampai generasi keempat). Sefalosporin yang lebih aktif terhadap kuman Gram negatif adalah generasi ketiga. Dari golongan obat ini yang pernah dicoba untuk pengobatan sepsis neonatorum adalah seftriakson, sefotaksim dan seftazidim. Keuntungan seftriakson, dosis yang diberikan kecil yaitu $50 \mathrm{mg} / \mathrm{kgbb} /$ hari dosis tunggal atau dibagi 2 dosis. Namun metabolisme obat ini terutama di hati, sehingga tidak dianjurkan pada pasien yang menderita ikterus. Sedangkan harga pengobatan sefotaksim lebih mahal, oleh karena dosis yang digunakan lebih besar yaitu $150 \mathrm{mg} / \mathrm{kgbb} / \mathrm{hari}$, apalagi bila dikombinasikan dengan aminoglikosid untuk melawan $P$. aeruginosa.

Seftazidim mempunyai potensi yang tinggi secara invitro, stabil terhadap inaktivasi betalaktamase, dan mempunyai spektrum luas terhadap banyak bakteri enterik Gram negatif, anaerob serta terhadap streptokokus. Seftazidim sangat efektif terhadap $P$. aeruginosa, Neisseria, $H$. influenzae tetapi kurang efektif pada pengobatan infeksi enterokokus. Seftazidim kurang aktif terhadap stafilokokus dibandingkan dengan sefalosporin generasi kedua. ${ }^{4}$

Di bagian IKA FK UNSRI / RSMH Palembang belum pernah dilakukan penelitian mengenai spektrum kuman penyebab sepsis neonatorum, sehingga belum ada gambaran sensitifitas kuman penyebab sepsis neonatorum terhadap antibiotik. Dari data rekam medik yang dikumpulkan dalam 9 bulan (Juni 1998 - Pebruari 1999) terdapat 134 kasus sepsis neonatorum. ${ }^{5}$ Dari observasi tersebut terlihat bahwa angka kematian pasien yang mendapat kombinasi ampisilin dan gentamisin 60,8\%, angka kematian pasien yang mendapat kombinasi ampisilin dan gentamisin yang kemudian diganti seftazidim adalah $30 \%$, sedangkan pasien yang langsung mendapat seftazidim dari awal mempunyai angka kematian 10,5\%. ${ }^{5}$ Dari pengamatan tersebut tampak bahwa pasien yang diobati ampisilin dengan gentamisin memperlihatkan respons klinis yang kurang baik dengan angka kematian yang tinggi. Oleh karena itu perlu dilakukan penelitian untuk membandingkan penggunaan kombinasi ampisislin dan gentamisin dengan seftazidim terhadap kasus sepsis neonatorum, sehingga dapat menentukan apakah kombinasi ampisislin dan gentamisin masih efektif.

\section{Bahan dan Cara}

Subyek penelitian adalah semua pasien tersangka sepsis neonatorum yang dirawat di bangsal Neonatus IKA RSMH dengan berat lahir $\geq 2500$ gram. Jika pasien pernah mendapat pengobatan antibiotik sebelumnya atau memiliki kelainan kongenital berat yang mematikan (anensefali, gastroschizis, omphalocele) dikeluarkan dari penelitian. Pasien yang memenuhi persyaratan penelitian dilakukan pemeriksaan anamnesis yaitu identifikasi, riwayat penyakit sekarang, riwayat kehamilan ibu, riwayat persalinan ibu. Pada saat masuk rumah sakit dilakukan pemeriksaan yang meliputi berat badan, aktifitas, refleks isap, tangis, laju denyut jantung, laju napas, suhu rektal, fungsi sistem saluran cerna, kardiovaskular, dan napas, serta ada tidak perdarahan. Sampel dibagi dengan cara undian yang terdiri dari 2 kelompok yaitu kelompok yang mendapat ampisilin dan gentamisin dan kelompok lain seftazidim. Peneliti tidak mengetahui apakah terapi yang diberikan kombinasi ampisilin dan gentamisin atau seftazidim tetapi diketahui oleh dokter bangsal. Dosis yang diberikan adalah:

- Ampisilin 100 mg/kgbb/hari intravenga dibagi 2 kali pemberian untuk umur $<7$ hari

- Ampisilin $200 \mathrm{mg} / \mathrm{kgbb} / \mathrm{hari}$ intravenga dibagi 3 kali pemberian untuk umur $>7$ hari

- Gentamisin 2,5 mg/kgbb/hari intravenga tiap 18 jam untuk umur $<7$ hari

- Gentamisin 2,5 mg/kgbb/hari intravenga tiap 12 jam untuk umur $>7$ hari 
Sari Pediatri, Vol. 3, No. 2, September 2001

- Seftazidim $50 \mathrm{mg} / \mathrm{kgbb} /$ hari intravenga tiap $12 \mathrm{jam}$

Pemeriksaan laboratorium meliputi kadar hemoglobin, leukosit, hitung jenis, laju endap darah, trombosit, CRP, dan biakan darah. Setiap hari dilakukan pemeriksaan fisik untuk menilai kemajuan pengobatan, yaitu aktifitas, refleks isap, tangis, laju denyut jantung, laju pernafasan, suhu, berat badan, kelainan klinis yang sebelumnya ada dan kelainan klinis yang baru timbul.

Pasien yang mendapat kombinasi ampisilin dan gentamisin jika keadaan umumnya memburuk atau secara klinis tidak ada respons dalam waktu 2 × 24 jam, terapi segera diganti dengan seftazidim. Penggantian obat dilakukan oleh dokter bangsal dan diketahui oleh penyelia bangsal Neonatologi. Pada kedua kelompok subjek selain antibiotik diberikan juga terapi suportif sesuai dengan keadaan klinis pasien. Terapi yang diberikan berupa cairan, koreksi keseimbangan asam basa, oksigenisasi, dan bila perlu diberikan transfusi darah.

\section{Pengolahan Data}

Data dicatat pada formulir isian penelitian, kemudian dimasukkan ke dalam komputer dengan program Epi-info versi 6.0. Selanjutnya data kontinus dianalisis dengan menggunakan uji-t atau bila tidak memenuhi syarat menggunakan uji Kruskal-Wallis, sedangkan data kategori dianalisis dengan uji chi-square dan bila tidak memenuhi syarat menggunakan uji Fisher exact.

\section{Hasil dan Pembahasan}

\section{Karakteristik subjek}

\section{Karakteristik Umum}

Selama periode penelitian dari bulan Oktober 1999 sampai dengan Juli 2000 didapatkan 53 subyek tersangka sepsis neonatorum yang memenuhi kriteria penelitian. Dari 53 subyek tersebut 3 orang dikeluarkan dari penelitian oleh karena pasien pulang paksa. Pasien tersebut adalah dua orang dari kelompok kombinasi ampisilin dan gentamisin dan 1 orang dari kelompok seftazidim, sehingga subyek yang dimasukkan ke dalam penelitian ini 50 subyek. Dari 50 subyek, masingmasing kelompok terdiri dari 24 orang mendapat kombinasi ampisilin dan gentamisin dan 26 orang mendapat seftazidim.

Kasus terdiri dari 27 (54\%) orang bayi laki-laki dan 23 (46\%) orang bayi perempuan. Dari seluruh sampel 17 bayi lahir di RSMH dan 33 bayi lahir di luar RSMH. Semua bayi mempunyai berat lahir $\geq 2500$ g. Usia pasien berkisar dari 1 hari sampai 28 hari yang terdiri dari bayi berumur $\leq 4$ hari (sepsis awitan cepat) $36(72 \%)$ orang dan berumur $>4$ hari (sepsis awitan lambat) $14(28 \%)$ orang. Dari hasil biakan darah didapatkan $30(60 \%)$ kasus biakan positif dan 20 (40\%) kasus biakan negatif.

Dari Tabel 1 terlihat bahwa bayi laki-laki lebih banyak dibandingkan bayi perempuan, 54\% berbanding $46 \%$. Bayi yang berumur $<4$ hari lebih banyak daripada bayi yang berumur $>4$ hari, $72 \%$ berbanding

Tabel 1. Karakteristik umum subjek penelitian

\begin{tabular}{lcccc}
\hline Variabel & Jumlah & \multicolumn{2}{c}{ Kelompok penelitian } & \multirow{2}{*}{$\rho$} \\
\cline { 3 - 4 } & & Ampi + Gentamisin & Seftazidim & \\
\cline { 3 - 4 } $\begin{array}{l}\text { Umur (hari) } \\
\quad \leq 4\end{array}$ & 36 & 18 & 18 & 0,89 \\
$\quad \begin{array}{l}> \\
\text { Kelamin }\end{array}$ & 14 & 6 & 8 & \\
$\quad$ Laki-laki & 27 & 16 & 11 & 0,15 \\
$\quad$ Perempuan & 23 & 8 & 15 & \\
Asal & & & & \\
$\quad$ RSMH & 17 & 10 & 7 & 0,42 \\
$\quad$ Luar RSMH & 33 & 14 & 19 & \\
Faktor risiko & & & 10 & 0,81 \\
$\quad$ Ada & 21 & 11 & 16 & \\
$\quad$ Tidak ada & 29 & 13 & & \\
\hline
\end{tabular}


28\%. Berdasarkan tempat lahir, tampak lebih banyak bayi lahir di luar RSMH (60\%). Faktor risiko terjadinya infeksi terdapat pada 21 orang (42\%). Dari Tabel 1 tampak pula bahwa tidak ada perbedaan yang bermakna dalam hal umur, jenis kelamin, tempat lahir, dan ada tidaknya faktor risiko infeksi antara kelompok yang mendapat ampisilin dan gentamisin dengan kelompok yang mendapat seftazidim.

\section{Gejala Klinis}

Pada 50 kasus tersangka sepsis neonatorum yang teliti, gejala klinis yang terbanyak adalah hipoaktif $\&$ refleks isap lemah masing-masing $29(58 \%)$ pasien, diikuti tangis lemah 28 (56\%) pasien, dispnu 23 (46\%) pasien, takipnu $\&$ hepatomegali masing-masing 22
(44\%) pasien, ikterus 19 (38\%) pasien, sianosis \& kejang masing-masing 18 (36\%) pasien, dan hipertemi 17 (34\%) pasien. Gejala klinis lain yang ditemukan adalah dehidrasi 14 (28\%) pasien, letargi $10(20 \%)$ pasien, meteorismus $9(18 \%)$ pasien, hipotermi, apne $\&$ muntah masing-masing $8(16 \%)$ pasien, anemia $6(12 \%)$ pasien, diare $5(10 \%)$ pasien, sklerema 4 (8\%) pasien, syok dan diatesis hemoragik ditemukan masing-masing $3(6 \%)$ pasien. Gejala klinis pasien tersangka sepsis neonatorum dapat dilihat pada Tabel 2.

Dari Tabel 2 dapat dilihat bahwa tidak ada perbedaan yang bermakna antara gejala klinis saat masuk rumah sakit antara kelompok kombinasi ampisilin dan gentamisin dengan kelompok seftazidim.

Tabel 2 Gambaran gejala klinis penderita tersangka sepsis neonatorum kelompok kombinasi ampisilin dan gentamisin dan kelompok seftazidim $(\mathrm{n}=50)$

\begin{tabular}{|c|c|c|c|c|}
\hline \multirow[t]{2}{*}{ Manifestasi Klinis } & \multirow[t]{2}{*}{$\Sigma$} & \multicolumn{2}{|c|}{ Kelompok penelitian } & \multirow[t]{2}{*}{$\rho$} \\
\hline & & Amp + Genta & Sefatazidim & \\
\hline \multicolumn{5}{|l|}{ Gejala Umum } \\
\hline Hipoaktif & 29 & 12 & 17 & 0,42 \\
\hline Refleks isap lemah & 29 & 12 & 17 & 0,42 \\
\hline Tangis lemah & 28 & 11 & 17 & 0,27 \\
\hline Hipotermi & 8 & 5 & 3 & 0,70 \\
\hline Hipertermi & 17 & 5 & 12 & 0,11 \\
\hline Sklerema & 4 & 2 & 2 & 0,99 \\
\hline \multicolumn{5}{|l|}{ Gejala gastrointestinal } \\
\hline Muntah & 8 & 3 & 5 & 0,70 \\
\hline Diare & 5 & 3 & 2 & 0,66 \\
\hline Hepatomegali & 22 & 12 & 10 & 0,46 \\
\hline Meteorismus & 9 & 4 & 5 & 0,99 \\
\hline \multicolumn{5}{|l|}{ Gejala saluran pernapasan } \\
\hline Dispne & 23 & 12 & 11 & 0,79 \\
\hline Takipne & 22 & 10 & 12 & 0,97 \\
\hline Apne & 8 & 4 & 4 & 0,99 \\
\hline Sianosis & 18 & 8 & 10 & 0,93 \\
\hline \multicolumn{5}{|c|}{ Gejala sistem kardiovaskular } \\
\hline Dehidrasi & 14 & 5 & 9 & 0,44 \\
\hline Syok & 3 & 1 & 2 & 0,99 \\
\hline \multicolumn{5}{|l|}{ Gejala SSP } \\
\hline Letargi & 10 & 4 & 6 & 0,73 \\
\hline Kejang & 18 & 6 & 12 & 0,21 \\
\hline \multicolumn{5}{|l|}{ Gejala hematologi } \\
\hline Anemia & 6 & 3 & 3 & 0,99 \\
\hline Diatesis hemoragik & 3 & 1 & 2 & 0,99 \\
\hline Ikterus & 19 & 6 & 13 & 0,06 \\
\hline
\end{tabular}




\section{Laboratorium}

Gambaran laboratorium 50 pasien tersangka sepsis neonatorum pada kelompok ampisilin dan gentamisin dan kelompok seftazidim dapat dilihat pada Tabel 3 di bawah ini.

Dari hasil pemeriksaan laboratorium saat masuk rumah sakit didapatkan $\mathrm{Hb} 12 \mathrm{~g} \%$, leukopeni (7), leukositosis (14), ratio IT $\geq 0,2$ (19), trombosit < $150.000 /$ ul (27), LED abnormal (22), CRP $\geq 12$ $\mathrm{mg} / \mathrm{dl}$ (27). Dari Tabel 3 terlihat bahwa tidak ada perbedaan bermakna gambaran laboratorium antara kelompok kombinasi ampisilin dan gentamisin dengan kelompok seftazidim.

Jika dilihat dari hasil biakan darah, pada kelompok kombinasi ampisilin dan gentamisin, didapatkan biakan darah positif pada 13 orang dan 11 orang dengan biakan negatif. Sementara itu 17 orang dari kelompok seftazidim hasil biakan darah positif dan 9 orang biakan darah negatif. Perbandingan antara hasil biakan kelompok kombinasi ampisilin dan gentamisin dengan kelompok seftazidim dapat dilihat pada Tabel 4.

Dari Tabel 4 di atas tampak bahwa hasil biakan antara kelompok kombinasi ampisilin dan gentamisin dengan kelompok seftazidim tidak ada perbedaan yang bermakna.

\section{Respons Klinis}

Respons klinis pada kedua kelompok kombinasi ampisilin dan gentamisin dan kelompok seftazidim dapat dilihat dari hasil pengobatan.

Tabel 3. Gambaran laboratorium kelompok kombinasi ampisilin dan gentamisin dan kelompok seftazidim saat masuk rumah sakit

\begin{tabular}{|c|c|c|c|c|}
\hline \multirow[t]{2}{*}{ Laboratorium } & \multirow[t]{2}{*}{$\Sigma$} & \multicolumn{2}{|c|}{ Kelompok penelitian } & \multirow[t]{2}{*}{$\rho$} \\
\hline & & Amp + Genta & Sefatazidim & \\
\hline \multicolumn{5}{|l|}{ Hemoglobin $(\mathrm{g} / \mathrm{dl})$} \\
\hline$\leq 12$ & 6 & 3 & 3 & \multirow{2}{*}{0,99} \\
\hline$>12$ & 44 & 21 & 23 & \\
\hline \multicolumn{5}{|l|}{ Leukosit ( /ul) } \\
\hline$<5000$ & 7 & 3 & 4 & \multirow{3}{*}{0,73} \\
\hline $5000-10000$ & 29 & 13 & 16 & \\
\hline$>25.000$ & 14 & 10 & 4 & \\
\hline \multicolumn{5}{|l|}{ Ratio } \\
\hline$<0,2$ & 31 & 17 & 14 & \multirow{2}{*}{0,22} \\
\hline$\geq 0,2$ & 19 & 7 & 12 & \\
\hline \multicolumn{5}{|l|}{ Trombosit ( /ul) } \\
\hline$<150.000$ & 27 & 10 & 17 & \multirow{2}{*}{0,16} \\
\hline$\geq 150.000$ & 23 & 14 & 9 & \\
\hline \multicolumn{5}{|l|}{$\operatorname{LED}(\mathrm{mm} / \mathrm{jam})$} \\
\hline Umur $\leq 7 \mathrm{hr}(>5)$ & 15 & 9 & 6 & 0,23 \\
\hline Umur $>7 \mathrm{hr}(>10)$ & 7 & 3 & 4 & 0,97 \\
\hline \multicolumn{5}{|l|}{ CRP positif (mg/dl) } \\
\hline$\geq 12$ & 27 & 13 & 14 & 0,98 \\
\hline$<12$ & 23 & 11 & 12 & \\
\hline
\end{tabular}

Tabel 4. Hasil biakan darah pada kelompok kombinasi ampisilin dan gentamisin dan kelompok seftazidim

\begin{tabular}{cccc}
\hline Hasil biakan & \multicolumn{2}{c}{ Kelompok penelitian } & $\rho$ \\
\cline { 2 - 2 } & Ampi + Genta & Seftazidim & \\
\hline Positif & $13 / 24$ & $17 / 26$ & 0,60 \\
Negatif & $11 / 24$ & $9 / 26$ & \\
\hline
\end{tabular}


Respons klinis pada kelompok yang mendapat kombinasi ampisilin dan gentamisin.

Terdapat 24 pasien yang mendapat terapi kombinasi ampisilin dan gentamisin, respons terhadap pengobatan dapat dilihat pada Tabel 5. dan 4 orang memberikan respons baik. ${ }^{6} \mathrm{Hal}$ ini mungkin oleh karena jumlah sampel dengan biakan positif lebih sedikit. Dari 11 orang dengan biakan negatif, 2 orang sembuh dan 9 orang gagal yang terdiri dari 1 orang meninggal dan 8 orang pindah ke kelompok seftazidim.

Tabel 5. Hasil pengobatan kombinasi ampisilin dan gentamisin berdasarkan hasil biakan pada pasien tersangka sepsis neonatorum

\begin{tabular}{cccc}
\hline Kultur darah* & \multicolumn{2}{c}{ Hasil pengobatan } & \\
\cline { 2 - 3 } & Gagal & Baik & Total \\
\hline Positif & 13 & 0 & \\
& $(100 \%)$ & $(0 \%)$ & 13 \\
Negatif & 9 & 2 & 11 \\
& $(81,8 \%)$ & $(18,2 \%)$ & 24 \\
\hline Total & 22 & 2 & 24 \\
\hline
\end{tabular}

Uji Fisher exact $\quad \rho=27 \quad *_{\mathrm{n}}=24$

Pada Tabel 5 terlihat bahwa dari 24 kasus kelompok kombinasi ampisilin dan gentamisin, 13 orang dengan biakan positif dan 11 orang dengan biakan negatif. Dari 13 orang biakan positif semua gagal dengan kombinasi ampisilin dan gentamisin, dengan perincian 1 orang pasien belum sempat diganti obat kemudian meninggal dan 12 orang mendapat ganti obat seftazidim. Pasien yang meninggal dengan hasil biakan $A$. calcoaceticus. Berbeda dengan hasil penelitian Monintja tahun 1986 yang membandingkan kombinasi ampisilin dan gentamisin dengan seftriakson, dari 21 pasien sepsis neonatorum dengan biakan positif 17 gagal
Respons klinis pada kelompok yang mendapat kombinasi ampisilin dan gentamisin kemudian diganti seftazidim

Terdapat 20 kasus yang sebelumnya mendapat kombinasi ampisilin dan gentamisin tetapi kemudian karena tidak ada perbaikan klinis atau terdapat perburukan dalam 2-3 hari, obat diganti dengan seftazidim. Respons klinis terhadap pengobatan lanjutan dengan seftazidim dapat dilihat pada Tabel 6.

Pada Tabel 6 tampak dari 20 pasien yang sebelumnya mendapat kombinasi ampisilin dan gentamisin diganti seftazidim terdiri dari 12 orang

Tabel 6. Hasil pengobatan kombinasi ampisilin dan gentamisin yang kemudian diganti seftazidim berdasarkan hasil biakan darah pada tersangka sepsis neonatorum

\begin{tabular}{lccc}
\hline Biakan darah & \multicolumn{2}{c}{ Hasil pengobatan } & \multirow{2}{*}{ Total } \\
\cline { 2 - 3 } & Gagal & Baik & \\
\hline Positif & 3 & 9 & 12 \\
Negatif & $(25 \%)$ & $75 \%)$ & \\
& 0 & 8 & 8 \\
\hline Total & $(0 \%)$ & $(100 \%)$ & \\
\hline $\mathrm{n}=20$ & 3 & 17 & 20 \\
\hline
\end{tabular}


dengan biakan positif dan 8 orang dengan biakan negatif. Dari 12 orang dengan biakan positif, 9 orang sembuh dan 3 meninggal. Dua belas orang yang pindah ke seftazidim, didapatkan kuman penyebab: $P$. aeruginosa (6 kasus), A. calcoaceticus (3 kasus), $S$. epidermidis (2 kasus) dan E. coli (1 kasus). Dari 3 kasus yang meninggal didapatkan hasil biakan $P$. aeruginosa pada 2 kasus dan E. coli 1 kasus. Sedangkan dari 8 orang dengan hasil biakan negatif, sembuh semua.

\section{Respons klinis pada pasien yang langsung mendapat seftazidim}

Pada 26 pasien yang sejak awal langsung mendapat seftazidim, respons klinisnya dapat dilihat pada Tabel 7.

Dari Tabel 7 terlihat bahwa dari 26 kasus yang langsung mendapat seftazidim, 17 orang dengan hasil biakan positif dan 9 orang biakan negatif. Dari 17 orang dengan biakan positif, 16 orang sembuh dan seorang meninggal dengan hasil biakan $A$. calcoaceticus. Kuman penyebab 16 kasus yang sembuh terdiri dari
A. calcoaceticus (6 kasus), E. coli (2 kasus), P. aeruginosa (2 kasus), S. aureus (1 kasus), S. epidermidis (2 kasus), S. viridans (1 kasus), K. pneumonia (2 kasus). Dari 9 orang dengan biakan negatif, 7 orang sembuh dan 2 meninggal. Untuk melihat keberhasilan pengobatan sepsis neonatorum pada kedua kelompok secara keseluruhan dapat dilihat pada Tabel 8.

Dari Tabel 8 tampak bahwa pada kelompok kombinasi ampisilin dan gentamisin hanya 8,3\% yang memberikan respons klinis baik (interval kepercayaan 95\%, 1-27\%), 91,7\% di antaranya tidak menunjukkan respons yang baik. Hasil penelitian ini hampir sama dengan hasil penelitian Monintja tahun 1986, dari 21 kasus sepsis neonatorum dengan biakan positif yang mendapat kombinasi ampisilin dan gentamisin, 4 orang dengan hasil baik dan 17 gagal (81\%). ${ }^{6}$ Sebaliknya dari kelompok seftazidim 88,5\% menunjukkan respons klinis baik (interval kepercayaan 95\%, 69,8-97,6\%) dan angka kegagalan 11,5\%. Terdapat perbedaan bermakna antara hasil pengobatan kombinasi ampisilin dan gentamisin dengan seftazidim. Hasil pengobatan seftazidim jauh lebih baik dibanding dengan kombinasi ampisilin dan

Tabel 7. Hasil pengobatan yang langsung mendapat seftazidim berdasarkan biakan pada pasien tersangka sepsi neonatorum

\begin{tabular}{lccc}
\hline Biakan darah & \multicolumn{2}{c}{ Hasil pengobatan } & \multirow{2}{*}{ Total } \\
\cline { 2 - 3 } & Gagal & Baik & \\
\hline Positif & 1 & 16 & 17 \\
Negatif & $(6 \%)$ & $(94 \%)$ & \\
& 2 & 7 & 9 \\
\hline Total & $(22 \%)$ & $(78 \%)$ & \\
\hline $\mathrm{n}=26$ & 3 & 23 & 26 \\
\hline
\end{tabular}

Tabel 8. Perbandingan hasil pengobatan pada kelompok yang dari awal mendapat kombinasi ampisilin dan gentamisin dan kelompok yang langsung mendapat seftazidim

\begin{tabular}{lccc}
\hline Kelompok penelitian & \multicolumn{2}{c}{ Hasil pengobatan } & Total \\
\cline { 2 - 3 } & Gagal & Baik & \\
\hline Ampisilin + Gentamisin & 22 & 2 & \\
Seftazidim & $(91,7 \%)$ & $(8,3 \%)$ & 24 \\
& 3 & 23 & \\
\hline Total & $(11,5 \%)$ & $(88,5 \%)$ & 26 \\
\hline $\mathrm{P}=0,0000$ & 25 & 25 & 50 \\
\hline
\end{tabular}


gentamisin, dengan nilai RR 7,9 artinya risiko gagal kelompok kombinasi ampisilin dan gentamisin 7,9 kali lebih besar daripada kelompok seftazidim.

Untuk melihat hasil pengobatan pasien yang semula mendapat kombinasi ampisilin dan gentamisin oleh karena tidak ada respons atau keadaan umum memburuk dalam 2-3 hari, kemudian diganti seftazidim tampak pada Tabel 9.

Dari Tabel 9 di atas tampak 4 pasien yang tetap mendapat kombinasi ampisilin dan gentamisin, 2 meninggal $(50 \%)$ dan $2(50 \%)$ mempunyai respons klinis baik (sembuh). Dua puluh kasus yang pada awalnya mendapat kombinasi ampisilin dan gentamisin kemudian diganti seftazidim. Dari 20 orang tersebut 3 (15\%) gagal dan 17 orang sembuh (85\%), sedangkan 26 pasien dari kelompok yang langsung mendapat seftazidim 3 gagal $(11,5 \%)$ dan 23 sembuh $(88,5 \%)$.

\section{Spektrum kuman penyebab sepsis neonatorum dan sensitifas in vitro}

Untuk memastikan diagnosis dan menilai sensifitas
$6(20 \%)$ kasus. Bakteri penyebab yang terbanyak adalah A. calcoaceticus (11 kasus), diikuti $P$. aeruginosa (8), E.coli (3), Klebsiella pneumonia (2), S. epidermidis (4), serta S.aureus, S.viridans masing-masing 1 kasus (Tabel 5). Berbeda dengan hasil penelitian Monintja tahun 1986 yang terbanyak adalah P.aeruginosa diikuti Klebsiella, E.coli, Enterobacter aerogenes, S. marcescens dan streptococcus. ${ }^{6}$ Sedangkan Lydia (1986) menemukan kuman penyebab sepsis neonatorum adalah E.coli (12 kasus), Alkaligenes (8), Pseudomonas (4), Proteus (2), Paracolon (2), Staphylococcus (2), Streptococcus (1), Salmonella paratyphi (1) dan Aecobacter (1). ${ }^{5}$ Perbedaan ini sesuai dengan teori bahwa penyebab sepsis berbeda antara suatu tempat dengan tempat lain dan dari waktu ke waktu.

Jika dilihat dari persentase sensitifitas $A$. calcoaceticus, $P$. aeruginosa, E. coli, $K$. pneumonia dan $S$. epidermidis terhadap ampisilin berturut-turut 0,0 , 100, 0 dan $100 \%$, terhadap gentamisin berturut-turut $18,18,25,33,3,50$, dan 50\%. Sedangkan terhadap seftazidim 72,7, 100, 100, 0 dan 25. Hampir sama dengan hasil penelitian Monintja \& Faizah (1987)

Tabel 9. Hasil pengobatan pada berbagai kelompok kasus sepsis neonatorum

\begin{tabular}{lccc}
\hline \multicolumn{1}{c}{ Kelompok pengobatan } & \multicolumn{2}{c}{ Hasil pengobatan } & \multirow{2}{*}{ Jumlah } \\
\cline { 2 - 3 } & Gagal & Baik & \\
\hline Ampisilin + Gentamisin & 2 & 2 & 4 \\
Ampisilin + Gentamisin $\rightarrow$ Seftazidim & $(50 \%)$ & $(50 \%)$ & \\
& 3 & 17 & 20 \\
Seftazidim & $(15 \%)$ & $(85 \%)$ & \\
& 3 & 23 & 26 \\
\hline Jumlah & $(11,5 \%)$ & $(88,5 \%)$ & \\
\hline
\end{tabular}

kuman terhadap obat dilakukan biakan darah, hasil dapat dilihat pada Tabel 10.

Dari 50 kasus tersangka sepsis neonatorum, 30 $(60 \%)$ kasus biakan darah positif. Hasil ini tidak jauh berbeda dengan hasil penelitian oleh Gurses yang mendapatkan biakan positif pada 41 dari 66 kasus sepsis neonatorum (62\%). ${ }^{7}$ Monintja tahun 1988 mendapatkan biakan darah positif $58,49 \%$ dari pasien klinis sepsis neonatorum. ${ }^{3}$ Lydia dkk. mendapatkan 33 (62\%) kasus dengan biakan darah positif dari 52 kasus tersangka sepsis neonatorum. ${ }^{8}$

Di antara biakan darah positif terdiri dari kuman Gram negatif 24 (80\%) kasus dan kuman Gram positif
Tabel 10. Spektrum kuman pada 30 kasus terbukti sepsis neonatorum

\begin{tabular}{cc}
\hline Kuman penyebab & Jumlah kasus \\
\hline Gram negatif & $24(80 \%)$ \\
Acinetobacter calcoaceticus & 11 \\
Pseudomonas aeruginosa & 8 \\
E.coli & 3 \\
Klebsiella pneumoniae & 2 \\
Gram positif & $6(20 \%)$ \\
Staphylococcus epidermidis & 4 \\
Staphylococcus aureus & 1 \\
Streptococcus viridans & 1 \\
\hline
\end{tabular}


sensitifitas P.aeruginosa, E. coli dan Klebsiella terhadap ampisilin berturut-turut adalah 7,1,33,3 dan $0 \%$ dan terhadap gentamisin 10,7, 66,7, dan $41 \%$.

\section{Kesimpulan}

Hasil pengobatan seftazidim jauh lebih baik dibanding dengan kombinasi ampisilin dan gentamisin pada pengobatan sepsis neonatorum. Spektrum kuman penyebab sepsis neonatorum yang terbanyak adalah Gram negatif, yaitu A. calcoaceticus, P aeruginosa, E.coli, dan $K$. pneumonia, dan kuman Gram positif yang ditemukan adalah $S$. epidermidis, $S$. aureus, dan $S$. viridas.

Sensitifitas A. calcoaceticus, P aeruginosa, E-coli, $K$. pneumonia dan $S$. epidermidis terhadap ampisilin berturut-turut adalah 0, 0, 100, 0 dan 100\%; terhadap gentamisin adalah $18,8,25,33,3,50$ dan $50 \%$; sedangkan terhadap seftazidim adalah 72,7, 100, 100, 0 dan $25 \%$. Secara in-vitro sebagian besar kuman resisten baik terhadap ampisilin maupun gentamisin, sedangkan sebagian besar sensitif terhadap seftazidim.

\section{Daftar Pustaka}

1. Mandell Gl, Petri WA. Antimicrobial agents. Dalam: Goodman and Gilman's, penyunting. The pharmacological basis of therapeutics. New york, McGraw-Hill, 1996. h. 1073-101.

2. Jawet E. Prinsip kerja obat antimikroba. Dalam: Katrzug $\mathrm{BG}$, penyunting. Basic and clinical pharmacology. EGC, 1994.h.699-732.

3. Monintja HE. Experiences with neonatal septicemia. Maj Pharm dan Terapi Indon 1988; 71-8.

4. Snyder IS. Finog RG. b Lactam antibiotics. Dalam: Modern pharmacology. Bostos, Little, Brown and company, 1990. h. 555-74.

5. Laporan bangsal Infeksi Bagian IKA FK UNSRI / RSMH Palembang tahun 1998-1999.

6. Monintja HE. Investigations on the aetiology and antibiotic management of neonatal septicemia. Pediatric Indones, 1988; 28:105-15.

7. Gurses N. Enterobacter septicemia in neonates. The pediatric inf Dis J. 1995; 7:638-39.

8. Lydia K, Bahtera T, Adinoto S. Early diagnosa of of neonatal sepsis by buffy coat and peripheral blood examination. Maj Ked Indon, 1986; 36:535-41. 